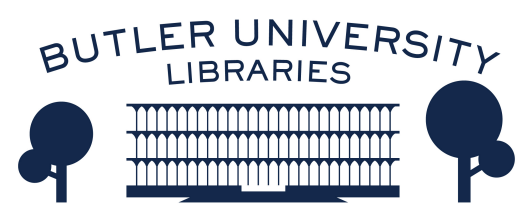

Journal of Hindu-Christian Studies

Volume 25

Article 23

November 2012

\title{
The Society for Hindu-Christian Studies
}

Follow this and additional works at: https://digitalcommons.butler.edu/jhcs

Part of the Religion Commons

\section{Recommended Citation}

(2012) "The Society for Hindu-Christian Studies," Journal of Hindu-Christian Studies: Vol. 25, Article 23. Available at: https://doi.org/10.7825/2164-6279.1529

The Journal of Hindu-Christian Studies is a publication of the Society for Hindu-Christian Studies. The digital version is made available by Digital Commons @ Butler University. For questions about the Journal or the Society, please contact cbauman@butler.edu. For more information about Digital Commons @ Butler University, please contact digitalscholarship@butler.edu. 


\section{The Society for Hindu-Christian Studies}

THE Society, founded in November 1994, is dedicated to the study of Hinduism and Christianity and their interrelationship. It seeks to create a forum for the presentation of historical research and studies of contemporary practice, for the fostering of dialogue and interreligious conversation, carried forward in a spirit of openness, respect, and true inquiry. Its scope includes issues related to religious practice, spirituality, and education.

Membership includes a subscription to the Society's Journal of Hindu-Christian Studies, which is published annually. Annual dues for membership plus a digital journal subscription are US \$30 annually (\$15 for individuals located in India; \$75 for a three-year membership). Annual dues for membership plus a digital and print journal subscription are $\$ 40$ annually ( $\$ 20$ for individuals located in India; $\$ 100$ for a three-year membership). Currencies other than U.S. dollars cannot be accepted. Go to www.hcstudies.org to join.

Annual meetings of the Society are held in conjunction with the American Academy of Religion annual meetings. For more information contact the Society's Secretary, Chad Bauman (cbauman@butler.edu).

\section{Annual Meeting Sessions November 16 and 18 Chicago, Illinois}

For membership information, please contact:

Bradley Malkovsky

(574) 631-0501

232 Malloy Hall

(574) 631-8209 fax

University of Notre Dame

bmalkovs@nd.edu

Notre Dame, IN 46556 